DOI: $10.1515 / \mathrm{rpp}-2016-0019$

$\mathrm{PhD}$ in Pedagogical Sciences, Associate Professor, BEATA ZIEBA University of Rzeszow, Poland Address: 16 C Al. Reitan St., Rzeszow, 35-959, Poland E-mail: ziebab482@gmail.com

\title{
PECULIARITIES OF FUTURE SOCIAL SPHERE SPECIALISTS' PROFESSIONAL TRAINING IN POLAND
}

\begin{abstract}
The article reviews certain aspects of organising the process of professional training of future specialists in social sphere. It identifies, considers and analyzes the main definitions of scientific research, the object of which is to make specialists in social sphere ready for professional activity. The article highlights peculiarities of forming professionally significant personal qualities of social workers as well as their mature, objective system of values. The practical training with a focus on having the ability to apply effective creative approaches in solving social problems is identified as an important component of the comprehensive process of professional training of future specialists in social and pedagogical work. It emphasises the importance of the use of effective innovation in social and socioeducational institutions. It analyzes the problem of organizing student teaching, which includes ignoring the use of active forms and methods in the learning process, a lack of skills of professional activity. The article reveals potential opportunities for the practical activity which is most closely approximate to real professional situations as an opportunity to form a positive attitude towards oneself as a subject of the chosen professional activity and the formation of students as professionals. It forms the principles of future social sphere specialists' training. The article also highlights the need to direct the educational process towards formation of an individual creative approach and establishment of partnerships between education and social institutions.

Key words: professional training, social sphere specialist, innovative technologies, skills of professional activity, qualities of a social sphere specialist, values, special abilities, creative approach.

\section{INTRODUCTION}

In the recent decade the organization and implementation of social assistance to the population of Poland has seen significant positive changes, such as the development and implementation of innovative meaningful technologies of social prevention, social rehabilitation, social support, social adaptation of children and youth, preparation of them for independent life; revival of the social and pedagogical work in communities; update of the approaches to the work with volunteers, "difficult" children and youth on implementation of their right to participate in the life of society, decision-making etc. At the same time the following problems remain unresolved: different directions of approaches to understanding socio-educational activity; insufficient level of inter-departamental cooperation; lack of resources, particularly, human resources, for successful implementation of the corresponding activity; insufficiency and low priority of the social and preventive work with families in order to prevent negative phenomena.
\end{abstract}


Training and formation of future social sphere specialists' professionalism focus on making professionals who are ready for and capable of implementing innovations, being creative, actively transforming and acquiring the best domestic and foreign practices, knowledge, modern professional qualities, models and technologies, as well as all the qualities which would allow the future specialist to effectively implement innovation activity in social and socio-educational institutions. The nature and value of this professional readiness to the work of social sphere specialists is manifested in their willingness and ability to focus on effective creative approach in solving social problems, carrying out their professional activities based on the creation of new integration forms of socio-educational space using modern models, algorithms and technologies for solving the social problems of the younger generation and society as a whole.

The problem of future social sphere specialists' training in the context of Polish higher education institutions is topical for modern Polish researchers, who believe that lacking a timely solution to negative phenomena leads to the development of social dysfunction and pathological phenomena, which contradict the moral aspects of public life and result in appearance of deviant behaviour of not only individuals but even entire groups of various communities, especially minorities (Палюх, Зємба, 2012). This is why it is necessary to create such conditions for the future social sphere specialists which will contribute to understanding of the social importance of their professional activity.

\section{THE AIM OF THE STUDY}

The purpose of this article is to study and analyze peculiarities in professional training of future social sphere specialists in Poland.

\section{THEORETICAL FRAMEWORK AND RESEARCH METHODS}

Social science and practice has intensified in the recent years. The results of this intensification are reflected in the research and development of training for innovative activity at higher education institutions of social profile specialists (A. Horbovsky, M. Palyuh, T. Titova, K. Shmid et al.); forming readiness for certain types of professional activity (W. Kaminskaya, J. Makvayter, B. Olshak-Kshizhanovskaya, D. Rybczynskaya et al.); the ratio of readiness and attitude, as well as forming professionally significant qualities of the personality of a social worker (G. Kloska, T. Piyatek, R. Porzak, L. Pytka, A. Snegulskaya et al.); education development concept and organization of the educational process in higher education institutions (T. Alexander, B. Okon, B. Voynarovska, Z. Vyatrovsky et al.); scientific concepts of the professional's personality and the consistent patterns of his/her formation (J. Dombrowski, S. Kavoulya, M. Kozerk, M. Radohonsky et al.).

We shall note that forming professional readiness of future social sphere specialists in Poland is carried out spontaneously and is determined by a set of random factors, rather than a targeted psychological and pedagogical work with future specialists in this field.

The methods of this study include generalization and apprehension of the existing scientific approaches to defining problems of the research, study, analysis and synthesis of the peculiarities of future social sphere specialists' professional training in Poland.

\section{RESULTS}

Training and formation of future social sphere specialists' professionalism highlights not only the presence of the required high level of knowledge in various branches of science but also mastering a variety of professional skills and expertize as a specialist: forming constant interest in the personality and his/her worldview, professional tact and professional responsibility. It is these qualities that should be formed in the consciousness of the future specialist already since his or her time as a student. 
For example, D. Rybchinskaya and B. Olshak-Kshizhanovskaya define the following qualities which a social sphere specialist should acquire in the process of professional training: comprehensive education, competence, ability to make independent decisions, resourcefulness, communication, tactfulness, sincerity in communication, honesty, fairness, friendliness, reliability, politeness, restraint, being attentive, tolerance, respect for the dignity of others, perseverance, ability to defend own opinion, objectivity, consistency, vigour, logic in own actions, astuteness, responsibility, acquiescence (Rybczyńska, Olszak-Krzyżanowska, 1999).

These qualities are that value which should be "acquired" in order to be implemented in life, society and professionally. A. Snegulskaya states that the result of readiness for professional activity must be reflected in the care for the welfare of other people, satisfying their needs, including psychological ones, necessity to respect differences, needs in the opportunity of individuality development (Śniegulska, 2009).

K. Halas emphasizes that human values are an important motivating factor and a factor of cognitive development; values are a subject of intellectual interests, emotional experience and material desires of an individual. They activate imagination, associations and intuition, mobilize and release the powers which motivate one to knowing oneself, the objective reality and another person (Chałas, 2003).

The system of values of an individual changes his/her attitude to various individual and social problems. It is the direction and the power of life choices in all the existing planes and dimensions of human activity. The behaviour which is carried out in accordance with the values of an individual can be changed by the influence of a situation. What is important in this sphere is the assertion of the fact that the cognition of the structure of preferences of values may, to some degree, make it possible to predict the behaviour of an individual and society (Paluch, 2007).

Modern Polish researchers believe that an important task of the contemporary education is to implement the attitudes for readiness to accept cultural, ethnic, religious and worldview differences as well as traditional differences into the behaviour of a person; to confront different types of danger through proactive and preventive activities; to limit xenophobia, stereotypes and different manifestations of ideological fundamentalism and denomination; to form a sane, critical and rational identification with the problems of evolution and the foundations of the culture of social life, reduction of cognitive and emotional distance down to own experience and cognition of the system of values of other nations (Horbowski, 1997).

It takes an extremely large amount of time for the fundamental value - professional responsibility - to form among the future social sphere specialists. Improving the formation quality of the future specialist's professional responsibility is complicated by the absence of clear recommendations of conducting classes on vocation-related subjects and organizing practice, which leads to lowering the efficiency of pedagogical influence. It is important to use in the educational process such methods and teaching aids which provide a full participation of students in the process of their professional training in the context of educational cooperation; development of the student's own views on the problems posed and search for ways to solve them; forming independence and originality of thinking.

The practice of Polish higher education institutions proves that limiting the possibilities of mental activity of students in a lecture leads to a poor quality of learning and a decreased activity level of the students' mental focus (Chałas, 2003).

L. Gorban reasons that the interest in the chosen profession often dies during studies at the university, and, as a result, even an internally motivated choice of the future profession 
does not always guarantee success in professional fulfilment (Горбань, 2013). In order for the future graduate to be capable of mastering the latest educational technologies, it is necessary to significantly change the organization of the educational process at a higher education institution.

Ignoring active forms and methods in the educational process does not contribute to the formation and consolidation in the future social sphere specialists' professional responsibility; therefore, the educational process needs to use active learning methods and pedagogical situations, which are aimed at intensification of professional training; integration of theoretical knowledge and practical skills, provision of creative conditions for achieving to one's capacity, development of the future specialists' personality, inclusion of students in individual and collective forms of scientific and pedagogical activities with gradually increasing complexity of its contents and simulating real activity of a specialist, which is an obligatory prerequisite of formation of the future specialists' professional readiness.

T. Titova proposes to extend the arsenal of organizational forms of conducting classes, in which the major role will be given to debates, conversations, self-examination, "brainstorming", modelling, designing, defending creative projects, problem and situational tasks, didactic theatre, teaching the search for alternative solutions etc (Тітова, 2015).

The learning process organized in such a way should be regarded as organizing social and educational environment, the aim of which is to implement innovations in the methods of teaching and learning activities and professional development of future social sphere specialists, as well as developing interest in the search for the newest approaches to providing social services.

We shall note that it is only those students who have mastered the skills of professional activity during studies who demonstrate interest and confidence in the future professional activity. Such skills are acquired by students through participation in various social student organizations, work in summer camps etc. Thus, they have the opportunity to check the viability, feasibility, depth and efficiency of their own career choices.

The closer to the graduation a student is, the closer to the model his knowledge, skills and personal qualities must be. All this requires a revision of curricula and programs of all kinds of practices with the purpose of integrating them and bringing them closer to the realities of modern life. To do this the following principles must be observed in the course of the future social sphere specialists' pedagogical training:

- unity of the social and pedagogical theory and practice;

- the possibility of coordinating with courses and private practices;

- differentiation and individualization of students' training for professional activity;

- the principle of content optimization, that is, expansion and deepening of the education content on the basis of the latest trends in the way society functions, relying on the basic component of specialist training, testing of variable curricula and programs which exclude duplication of educational information, internal records and interdisciplinary connections; mastering the leading areas of socio-educational activities;

- the principle of humanization and humanitarization, which involves purposeful development of professionally significant qualities, development of the desired tone and style of relationship between the subjects of pedagogical process, the unity of common cultural, psychological and pedagogical and special training of the future social teacher;

- focus on in-depth study of the philosophy of education, which must ensure the understanding of essence of the processes of development and education (training/learning) 
as an interaction of universal human, specifically historical and national components of culture in the process of the personality's formation;

- focus on the personality as a subject of interaction;

- the connection of study of the psychological and pedagogical theory with teaching practice, integration of theoretical and methodic questions, the practice-oriented nature of teaching, correlation of theoretical positions and practices;

- focus on a holistic vision of the social and educational reality.

Only when the educational process at a higher education institution is built on these principles is when it will be able to record the following in the consciousness of the future graduate: professional responsibility, sustainable professional interest and a constant pursuit of his/her own professional development.

\section{CONCLUSIONS}

The problem of forming professionalism of the future specialist in social and pedagogical work in the context of pedagogical process is given much attention by scientists, who take notice of the necessity to use such methods and teaching means which will ensure full student participation in the process of his/her professional training in the context of cooperation, development by a student of his/her own view on the issues raised on the basis of assimilated scientific content, the formation of independent and original thinking. Organization of educational work must include variability of the learning content: theoretical component (a set of educational and methodical provision); practical component (inclusion of students into the organizational processes of carrying out future professional activity); independent work (doing individual assignments by students); engaging students in active public work.

Only when the educational process at a higher education institution is built on these principles is when it will be able to record the following in the consciousness of the future graduate: professional responsibility, sustainable professional interest and a constant pursuit of his/ her own professional development.

Given the experience of training of future social workers, the prospects for further research in this area require an analysis of educational, professional and evaluating programmes of the psychological and professional training of future specialists in social sphere.

\section{REFERENCES}

1. Chałas, K. (2003). Wychowanie ku wartościom. Elementy teorii i praktyki [Education to Values. Elements of Theory and Practice]. Kielce : Jedność, 390 p. (in Polish).

2. Horbowski, A. (1997). Pedagogika kultury czy edukacja kulturalna [The Pedagogy of Culture or Cultural Education]. Kultura elementem nowej strategii edukacyjnej. Rozprawy $i$ szkice [The Culture Element of the New Education Strategy. Hearings and Sketches], Kraków : Wydawnictwo Uniwersyteckie, 58 p. (in Polish).

3. Paluch, M. (2007). System wartosci polskiej i stowackiej młodzieży akademickiej $w$ kontekscie tozsamosci europejskiej. Diagnoza [The System of Values, Polish and Slovak Academic Youth in the Context of the Individual Union. Diagnosis]. Sanok : Wydział Pedagogiczny. Katolicki Uniwersytet, 119 p. (in Polish).

4.Rybczyńska, D., Olszak-Krzyżanowska, B. (1999). Aksjologia pracy socjalnej - wybrane zagadnienia [Axiology of Social Work - Selected Issues]. Katowice : Śląsk, 195 p. (in Polish). 
5. Śniegulska, A. (2009). Wychowanie do miłości drogą przezwyciężania przemocy w rodzinie [Nurturing Love, Overcoming Domestic Violence]. Miłość jako wartość we wspótczesnej pedagogice [Love as a Value in Modern Pedagogy], pp. 226-234 (in Polish).

6. Горбань, Л. (2013). Підготовка фахівиів сочіальної сфери до соиіальнопрофесійної орієнтації [Training of Social Sphere Specialists to the Socio-Professional Orientation]. К. : Інформаційні системи, 158 р. (in Ukrainian).

7. Палюх, М., Зємба, Б. А. (2012). Людина в небезпечній ситуачї̈. Багатовимірні аспекти соціальних патологій [People in a Dangerous Situation. Multidimensional Aspects of Social Pathologies]. Кам'янець-Подільський : Аксіома, 156 p. (in Ukrainian).

8. Тітова, Т. (2015). Проблема психологічного супроводу формування ціннісно-смислової сфери майбутніх психологів [The Problem of Psychological Support of the Formation of Value-Semantic Sphere of the Future Psychologists]. Психологія $i$ особистість [Psychology and Personality], No 1, pp. 176-185 (in Ukrainian). 